\title{
The figure of the woman in Sardinian theater of the 1970s: The case of the theater company La Maschera of San Sperate*
}

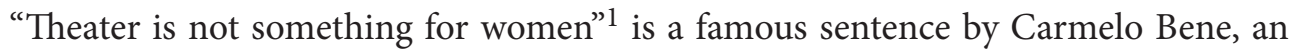
Italian actor, dramatist, director and poet, who was active in the mid-1990s. Perhaps there was a sort of historical reflection in him, because when theater started to become established, women had not been foreseen. With his quote, Bene was probably referring to the fatigue, the hardness of theatrical work, insinuating that women were too weak to deal with it. It is common knowledge that women, for centuries, have been excluded from the stage, even though most of the dramas performed used to include female figures and for morality reasons - the theater has long been considered scandalous - were replaced by men, possibly youths. It is thanks to the Italians, especially the Commedia dell'Arte, if they managed to tread the boards. ${ }^{2}$ It was because their companies were nomads around the world, and they brought wives and daughters with them in carts, as well as the tools of the profession. So, they thought about making them work. When the caravans of the commedia dell'arte started to

* I analyzed the figure of the actress Ida Pillitu and the case of the theater La Maschera of San Sperate through a direct interview with the actress, who answered several questions in order to tell her theatrical experience in Sardinia, and in addition I used the books and newspaper articles cited in the bibliography.

${ }^{1}$ L. Castellina, "Il teatro (non) è cosa per donne," in Il Teatro e il Mondo, 2016, no. 4, pp. 1-6; Toscana Spettacolo Onlus 2016, no. 4, p. 1.

2 M.R. Grifone, "Il teatro e il femminile," Dramma, p. 3, http://www.dramma.it/dati/monografie/ teatroefemminile.pdf (accessed: 6.01.2020). 
cross Europe, between the end of the 16th and the beginning of the 17th century, even other countries were struck by the audacity and decided to follow the Italians. Therefore, women had access to the stage beyond the Alps. The irruption of women somehow changed comedy and tragedy, representing a qualitative leap.

A new interest, both cultural and anthropological, underlies the extraordinary attention paid to the woman between humanism and the Renaissance. At the beginning of the 16th century, the female condition became the object of an intense reflection that involves the most different spheres and penetrates all literary genres. Both in the novella and in lyric poems, the woman is the center of a renewed curiosity. In the 16th century, theatrical dramas are full of general considerations entrusted both to choirs and to the characters: judgments that deal with all the most topical subjects and which cannot ignore the debate on the position of women. During Shakespeare's era, the theatrical profession was considered only a male issue. All around Europe, especially in France and Italy, there were at the same time fairly frequent examples of women acting on the stage. In England, instead, they did not appear until 1660, when for the first time an actress, Margaret Hughes, interpreted the part of Desdemona in Othello.

At the beginning of the 18th century, the centrality of female interpretation grew, becoming the pivot of stage action, and during the 19th century women, by virtue of a singular reversal of schemes, reached an enviable social integration. The theater, as one of the most important media between the late 19th and early 20th centuries, undoubtedly contributed to modifying common opinion, before cinema and TV began to take on a central role in Italian. Presenting an image of a woman who moved away, even minimally, from the role of a traditional mother and devoted wife, the theater has participated in the slow process of female emancipation, through its undeniable power to influence the audience. Women have conquered their own subjectivity on the stage that has often expressed itself in a non-homogeneous way, but which has given rise to a prolific production of texts and performances for them. From the awareness of their diversity, from a female point of view, therefore, something new has come to light for contemporary dramaturgy.

For its intrinsic substance, theater is among the arts most suitable to speak directly to the heart of the community. The theater plays with immediacy, with creation in the moment, with the act that dies at the same moment in which it takes place, with the unrepeatability of the story that evolves or is involved every time in a different way.

My paper is focused on the change of the social role of women within a theatrical and an artistic phenomenon that began at the end of the 1960s in San Sperate, a small Sardinian village a few kilometers away from Cagliari. It is the evolution of a small farming village, such as San Sperate, into an Open Air Museum, which in Italian is referred to as "Paese Museo," thanks to the revolutionary activity of the international artist Pinuccio Sciola and to the organizational capacity of a cultural association that brings together the whole social system of the village, from the student to the worker, the farmer, the 
journalist, the housewife. ${ }^{3}$ It is called an Open Air Museum because they started to paint the walls of the village with artists from all the world, following the Mexican muralismo. It is not just any museum because qualified figures from the literary, scientific, journalistic, theatrical and musical worlds participate in it. The commitment was to take art out of the traditional limits of the artist-gallery relationship, to bring the artist to work in the open air in direct contact with people and to turn culture into a truly common asset.

The overall vision of the Paese Museo is worthy of attention for its human and cultural content, but, above all, because it deepens Sardinian traditions, which are reinvented and relived with the decorative language of contemporary abstract and expressionist experiences. It confirms the modern concept of culture intended as a choral expression. The Paese Museo was one of the most authentic ways to bring people closer to art and culture, and to transform the interest of the few into a popular interest.

The experience of the Paese Museo approaches the neo-avant-gardes of the late 1960s with a new way of perceiving works of art, creating a link with other artistic disciplines such as music, dance and theater. ${ }^{4}$ The sense of participation in the experience of the Paese Museo is so strong that it translates into the birth of various initiatives, such as the theatrical group La Maschera (The Mask), born around 1964 in San Sperate, thanks to the initiative of some young theater lovers; ${ }^{5}$ a beautiful reality that still operates today. Initially the main activity of this group was the preparation of children for singing and music, theater and sports, but the first works of the theater company were addressed exclusively to the local public and consisted of short and very simple stories. The group consisted of both women and men, but initially only males were on the stage, and the girls used to help them to set the stage costumes and to get the sets ready for the stage.

I would like to focus my attention on Ida Pillitu, born in San Sperate in 1943. She used to be a housewife until she started to work for the theater when she was only 20 years old. She was one of the first girls to attend the cultural club and to actively participate in all the initiatives of the Paese Museo. The attendance of these activities gives Ida the opportunity to realize a dream: she has always been a determined girl who wanted to achieve her goals. She was the first who could drive people in her projects. She wanted to act as she had a natural talent for acting At the beginning some appreciated her acting skills and some did not. Indeed, someone said "if she was my daughter I would never have allowed her to do it." At that time the social role of the woman was of great formal respect, on the part of the man, but in the exclusively domestic sphere.

The absence of the man in the house led to women undertaking all the responsibilities that are inherent to the family: the bringing up of children, their education,

${ }^{3}$ G. Pilloni, Pinuccio Sciola. Racconti inediti di vita e arte dagli anni '60 agli anni '80, master's thesis, University of Cagliari 2017, p. 42.

${ }^{4}$ Ibid., p. 41.

${ }^{5}$ C. Porcu, Gli "anni della calce" e il Paese Museo, Selargius 2012, p. 22. 
homecare and the management of family's assets. At the end of the 1960s a few women started to have the opportunity to study and to create personal goals, independently from the family sphere, especially in a small reality like San Sperate.

To Ida it was even more difficult because in the village the men from the La Maschera were treated with suspicion because of the entertainment events organized and because of the revolutionary movement of muralismo or walls painted. Her mother's opinion was really important for Ida: initially she did not accept her choice, but when she understood how acting was satisfactory for her, she became her first admirer, contributing to the realization of her stage costumes.

Ida represents the model of a woman able to demonstrate such strength to overcome social prejudices, succeeding first in escaping the condition of social marginalization, and then succeeding in imposing herself in an artistic and theatrical world reserved only for men. Thanks to her curiosity and determination, she managed to live a more gratifying reality than what her parents had imagined for her.

Here below are Ida's thoughts that I would like to share:

I love acting. I never liked myself, I was plump, I did not use to see well, I was not appreciated, I think I had no value, but when I started to do theater, I realized that I was valued, that I was worth something, I saw myself as beautiful, when I came down from the stage and people complimented me, I told myself "then I'm worth something" and from then I've worked even harder. ${ }^{6}$

"I wanted to be the protagonist," she used to say to the other men in order to harmonize her acting with the one of the other actors. Because her script was not enough, she used to remember also the parts of the other actors.

Ida started to act in public in 1971 when the theater company she was working with began to produce more socially engaged shows: they started staging the works of Antonio Garau, one of the great representatives of the island's comediography. His works deeply express the soul and the Sardinian way of life and problems. Acting in the theater in Sardinia meant the protection of the language, culture, history and popular traditions. The attention and interest shown by the public led the group to create more committed comedies that, through laughter and jokes, led to the reflection and analysis of problems and situations of social life. They produced Garau's works like $\mathrm{Sa}$ Professoressa (The Teacher), Basciura (Low Zone), S'urtima Cena (The Last Supper).

As Ida mentioned during my interview, the goal of the company was to make people laugh and to entertain, hence the first name of the company, "Castigat ridendo mores," a Latin phrase that literally translated means "corrects customs by laughing," indicating how comedy and satire, spreading irony and ridicule at human vices and defects, contribute to the reform of customs. The intent was to bring the theater to

${ }^{6}$ Quote from the interview with the actress Ida Pillitu. Unless otherwise indicated, all translations are the author's.

7 Ibid.

${ }^{8}$ C. Porcu, op. cit., p. 71. 
the people, the reason why the performances were exclusively in Sardinian language, was conducive to the recovery of their roots. Thanks to the use of the Sardinian language and the representation of the performances in the town squares, La Maschera allowed people to approach theater who otherwise would have been excluded. ${ }^{9}$ After the local experience they had the opportunity to tour Sardinia, taking their "theater" everywhere and adapting the scenes and the dialogues of the works to their social fabric, making their language comprehensible to everyone.

Playing on the squares was much nicer, much more successful. We liked to look people in the eye. Our company was the first to play open air for people. The first time we played open air in San Sperate was for the Santa Prisca festival in May 1972. The square was full, so much so that the police had to close the streets. In the village, unexpectedly, I was ashamed, then once I went out onto the stage I worked even harder for those people who criticized and thought that we women would not be able to act like men. I always liked playing the part of the commoner, because I could express myself more. I have never worn a mask because on the stage I was myself. I managed to convey my person in the characters I played. ${ }^{10}$

The first official awards came in 1976 when La Maschera was invited by the president Carlo Ripa di Meana to Biennale Venice for the review Art and Environment, together with the activities of the Paese Museo and the artist Pinuccio Sciola. ${ }^{11}$ Towards Venice left the initiators of the Paese Museo, the Theater Cooperative of Sardinia, La Maschera of San Sperate, choral dance groups and players, and other journalists and intellectuals who wanted to proove with their presence the decentralization: more than 50 people giving a proper image of Sardinia, presenting Sardinian culture, not academic, committed, alive and itinerant. Their goals were: the recovery of a culture, always conditioned and oppressed, and representing the synthesis of cultural, social and political moments of Sardinia at that time, which could not fail to draw the attention of the critics present at the Biennale in the way of being Sardinian in an active and conscious sense.

The San Sperate artistic experience emphasized the need for a new way of communicating and creating, making art in human places, and therefore Sardinia did not rise on the stage but descended into the square, spoke with people and it was made known for what it was. Ida was the only woman present in Venice of the San Sperate group, and she still remembers the trip, the ups and downs, and the need to adapt to a rather precarious situation. She also remembers the privilege to be there in Venice and to participate in the construction of an event with a formidable impact. Ida never believed that she would have had this opportunity, not only to savor this artistic event, but to contribute as part of a theatrical group. They played the last piece of the comedy Sa Professoressa in Santa Margherita square. ${ }^{12}$ The comedy is a small slice of

${ }^{9}$ G. Pilloni, op. cit., p. 41.

10 Quote from the interview with the actress Ida Pillitu.

11 M. Faticoni, "La Sardegna a Venezia," Il Messaggero Sardo 7, 1976, no. 10.

12 L. Sole, “Una traccia sulla laguna," La Nuova Sardegna 17.10.1976. 
everyday life, always in the Sardinian language; there were more than 2,000 people in the audience, unaware of the language in which it was played, yet they were attracted by the overall expressiveness, by the stories they still managed to capture.

To Ida it was an unrepeatable event, one of those that leave a mark for a lifetime, because they were able to talk about Sardinian culture.

I suggest that the reader watches of a short video in Sardinian language, extracted from the 2009 San Sperate Cuncambias Theater Festival, where we can see Ida Pillitu and Mario Fulghesu, another member of the La Maschera, playing the last scene of the play Sa Professoressa, which plays on the reason of social elevation and the relationship between different social strata. ${ }^{13}$ The married couple Ciccittu and Filomena after having faced many sacrifices, anxieties and efforts to let their only daughter study, have her coming back home. She represents the hope of a new life, economic well-being and social prestige they always dreamed of. But reality is never like in the imagination, and the two parents only have the resignation of an old age of misery and loneliness.

In this comedy, what appears to be farcical at first becomes a drama, and laughter highlights serious problems that are always current, from school and work, to the condition of the elderly, isolated and increasingly marginalized. This last scene represents the greeting between the two characters, who after being married for more than 40 years cannot express their intimacy, not even in the form of a hug, underlining the embarrassment of two spouses at the end of the 1950s.

Here I translate Ida's final sentence, which, in my opinion, exemplifies the importance theater has had in her life:

I want to say something, the theater has given me so much satisfaction and I hope it will give me so much more. But believe me, when we talk about theater and the Mask, we talk about a whole life. ${ }^{14}$

\section{Bibliography}

Castellina L., "Il teatro (non) è cosa per donne," in Il Teatro e il Mondo, 2016, no. 4, pp. 1-6.

Casula T., "Commuoversi non basta," L'Unione Sarda 15.10.1976.

Faticoni M., "La Sardegna a Venezia," Il Messaggero Sardo 7, 1976, no. 10.

“La Sardegna alla Biennale," L'Unione Sarda 5.10.1976.

Naitza S., “Dalla Sardegna a Venezia. Una 'documentazione aperta' sull'isola alla Biennale '76," L'Unità 3.10.1976.

Nemos, "I nostri morti a Venezia," Il Popolo Sardo 23.10.1976.

Pilloni G., Pinuccio Sciola. Racconti inediti di vita e arte dagli anni '60 agli anni '80, master's thesis, University of Cagliari 2017.

Pintore G., "La pittura di S. Sperate alla Biennale di Venezia," La Nuova Sardegna 20.05.1976.

13 https://www.youtube.com/watch?v=pj7tab062tE (accessed: 6.01.2020).

${ }^{14}$ Ibid. 
Podda G., "Dalla Sardegna a Venezia. Una 'documentazione aperta' sull'isola alla Biennale '76," L'Unità 3.10.1976.

Porcu C., Gli "anni della calce" e il Paese Museo, Selargius 2012.

Protetty C., "La 'questione sarda' si abbatte sulla Biennale," Tutto Quotidiano 1.10.1976.

Rodriguez A., “Cadaveri e canne a Venezia," L’Unione Sarda 26.09.1976.

Rodriguez A., “I mori a Venezia," L'Unione Sarda 10.10.1976.

Sole L., "Una traccia sulla laguna," La Nuova Sardegna 17.10.1976.

“'Su connottu’ per gli emigrati," Tutto Quotidiano 29.10.1976.

\section{Internet sources}

Grifone M.R., "Il teatro e il femminile," Dramma, http://www.dramma.it/dati/monografie/teatroefemminile.pdf.

https://www.lamaschera.com.

https://www.youtube.com/watch?v=pj7tab062tE.

\section{The figure of the woman in Sardinian theater of the 1970s: The case of the theater company La Maschera of San Sperate}

\section{Summary}

This piece of resesch aims to study the emancipation of women in the world of theater through a particular case that occurred at the end of the 1960s in a small peasant town in southern Sardinia, San Sperate. Ida Pillitu is a woman who started acting and has been working in the La Maschera Theater Company since 1971, when they began to produce more socially engaged shows. I mainly conducted this research through some archive documents and an interview with Ida Pillitu, who revealed to me the effort and the determination with which she achieved her goals and her dream of becoming an actress.

Keywords: theater, Sardinia, actresses, Ida Pillitu, emancipation 